\title{
Microbial degradation of the leachable and lignocellulosic components of leaves and wood from Rhizophora mangle in a tropical mangrove swamp
}

\author{
Ronald Benner \& Robert E. Hodson \\ Department of Microbiology and Institute of Ecology, University of Georgia, Athens, Georgia 30602, USA
}

\begin{abstract}
Preparations of uniformly $\left[{ }^{14} \mathrm{C}\right]$ labeled mangrove leaves and specifically radiolabeled $\left[{ }^{14} \mathrm{C}\right.$-lignin]lignocelluloses and $\left[{ }^{14} \mathrm{C}\right.$-polysaccharide]lignocelluloses from mangrove leaves and wood were used in experiments to determine the microbial rates of mineralization of the leachable and lignocellulosic components of mangrove detritus in aerobic and anaerobic sediments of a tropical mangrove swamp. The bulk of the leachable fraction from mangrove leaves was mineralized relatively rapidly and was assimilated into microbial biomass with high efficiency $(30 \%)$. In contrast, rates of mineralization of the lignocellulosic component of mangrove leaves and wood were 10fold lower than mineralization rates of the leachable fraction. The polysaccharide component of the lignocelluloses was mineralized at rates 2 times higher than rates of mineralization of the lignin component, indicating that mangrove detritus becomes relatively enriched in lignin-derived carbon with time. Anaerobic rates of mineralization of the leachable and lignocellulosic components of mangrove leaves and wood were 10 to 30 times lower than respective aerobic mineralization rates, suggesting a very long residence time for mangrove detritus in anaerobic sediments. Comparison of the rates of degradation of mangrove detritus in sediments from a mangrove swamp and a salt marsh demonstrated that the lignocellulolytic potential in sediments of the two marine ecosystems are similar, but that lignocellulose from mangroves is less biodegradable than lignocellulose from the salt-marsh plants, Spartina alterniflora and Juncus roemerianus.
\end{abstract}

\section{INTRODUCTION}

Mangrove ecosystems fringe tropical and subtropical coastlines throughout the world functioning as nurseries for a wide variety of vertebrate and invertebrate marine species. Estimates of net aboveground primary production of mangroves vary considerably, with $730 \mathrm{~g} \mathrm{C} \mathrm{m}^{-2} \mathrm{yr}^{-1}$ being a representative value (Mann 1972, Lugo \& Snedaker 1974). Much of this production is in the form of leaves, of which only a small percentage ( 5 to $10 \%$ ) is consumed by terrestrial grazers (Heald 1971). The bulk of leaf biomass dies and enters the aquatic environment as detritus (Heald 1971). Thus, mangrove-derived detritus constitutes a large reservoir of carbon and energy potentially available to the estuarine food web. Roughly 30 to $50 \%$ of the organic matter in mangrove leaves are leachable, water-soluble compounds, such as tannins and sugars (Cundell et al. 1979); the remaining fraction of the organic matter presumably consists of plant structural polymers commonly referred to as lignocellulose.

Lignocellulose is a macromolecular complex of the structural polysaccharides, cellulose and hemicellulose, and the aromatic heteropolymer lignin. Lignocellulose is degraded by certain fungi and bacteria but is indigestible by most animals. Of the component polymers of lignocellulose, lignin is the most resistant to microbial degradation; in fact, due to the chemical bonding and close physical association between lignin and the polysaccharides, cellulose and hemicellulose, microbial degradation of the lignin component of lignocellulose is considered the rate-limiting step in lignocellulose biodegradation (Crawford 1981). The transfer of carbon and energy from mangrove detritus to animal consumers appears to occur via grazing of easily digestible and highly nutritive microbial biomass resulting from bacterial and fungal transformation of the lignocellulosic detritus. In this way, man- 
grove detritus serves as the base of an elaborate and productive food web in tropical and subtropical coastal marine environments (Odum \& Heald 1972, Rodelli et al. 1984). Therefore, factors influencing rates of microbial degradation of the leachable and lignocellulosic components of mangrove detritus directly control the rates of heterotrophic microbial production and nutrient regeneration, and indirectly affect the rates of secondary production by animals in the mangrove ecosystem.

Considering the quantitative significance of lignocellulose as a major component of mangrovederived detritus, surprisingly little is known about the transformations and fate of lignocellulose in mangrove swamps and adjacent coastal environments. In part, this dearth of information results from a lack of methodology sufficiently sensitive and selective to track the low rates of biodegradation of the lignin and polysaccharide components of lignocellulose. Recently, we optimized methodology to specifically radiolabel the lignin or polysaccharide components of natural lignocellulose in a variety of aquatic plants (Benner et al. 1984a). Incubation of these radiolabeled preparations under field or laboratory conditions makes possible the determination of individual rates of microbial degradation of the lignin and polysaccharide components of detritial lignocelluloses.

To date, we have used specifically radiolabeled lignocelluloses to determine the rates of aerobic and anaerobic mineralization of $\left[{ }^{14} \mathrm{C}\right.$-lignin]lignocelluloses and $\left[{ }^{14} \mathrm{C}\right.$-polysaccharide|lignocelluloses derived from aquatic macrophytes, such as the salt-marsh cordgrass Spartina alterniflora and the black needlerush Juncus roemerianus, in sediments from a Georgia salt marsh (Maccubbin \& Hodson 1980, Hodson et al. 1983, Benner et al. $1984 a$, b). We have also determined rates of degradation of lignocellulose from the sedge Carex walteriana in sediments of the Okefenokee Swamp, a large, acidic $(\mathrm{pH} 3.8$ to 4.2$)$ freshwater wetland in southern Georgia (Benner et al. 1984b, Benner et al, in press). In sediments of both of these ecosystems, aerobic rates of degradation of lignocelluloses are typically much higher than anaerobic rates of degradation; 15 to $30 \%$ of the lignocelluloses are mineralized aerobically during $25 \mathrm{~d}$ incubations, whereas $250 \mathrm{~d}$ of incubation are required to mineralize a similar percentage of the lignocelluloses under anaerobic conditions (Benner et al. 1984b). In general, the polysaccharide components of lignocelluloses from aquatic plants are mineralized at rates several times those of the lignin component, resulting in the gradual enrichment of the detritus in lignin-derived carbon. Concomitant with a gradual increase in the relative lignin content of the lignocellulosic detritus, rates of biodegradation of the lignocellulose decrease logarithmi- cally, indicating that the material becomes increasingly recalcitrant to microbial degradation with time (Benner et al. 1984a, Hodson et al. 1984). Rates of degradation of any particular lignocellulose were slower in Okefenokee Swamp sediments relative to salt-marsh sediments due primarily to effects of $\mathrm{pH}$ (Benner et al. in press).

In the present study, we characterized the kinetics of microbial degradation of mangrove detritus by mangrove-swamp microflora and compared the microbial degradation of detritus in this tropical, detritus-based ecosystem with microbial degradation of detritus in a temperate, salt-marsh ecosystem. We determined the rates of biodegradation of both the lignocellulosic and leachable components of leaves and wood of the red mangrove Rhizophora mangle under aerobic and anaerobic conditions in water and sediment from various locations in the Fresh Creek estuary, an expansive mangrove swamp on Andros Island, Bahamas. Kinetics of the early stages of microbial degradation of mangrove detritus were characterized by following the fate of carbon from uniformly radiolabeled leaf material. Kinetics of the latter stages of microbial degradation of mangrove detritus were investigated using specifically radiolabeled $\left[{ }^{14} \mathrm{C}\right.$-lignin $]$ lignocelluloses and $\left[{ }^{14} \mathrm{C}\right.$-polysaccharide]lignocelluloses from leaves and wood of $R$. mangle. The leachable, water-soluble components of mangrove leaf material were relatively rapidly mineralized, whereas the lignocellulosic component was very resistant to biodegration and was mineralized much more slowly. Comparison of the rates of mineralization of mangrove lignocellulose in sediments from Fresh Creek estuary with rates of mineralization of Spartina alterniflora lignocellulose in sediments from a temperate salt marsh indicate that the turnover times of mangrove detritus are much longer than turnover times of lignocellulosic detritus in salt marshes, which are dominated by herbaceous plant species.

\section{MATERIALS AND METHODS}

Preparation of radiolabeled substrates. Leaves from Rhizophora mangle were uniformly radiolabeled with ${ }^{14} \mathrm{C}$ by incubating 2 freshly cut living stems with 15 to 25 leaves each, in $\mathrm{CO}_{2}$-impermeable Mylar bags (Benner et al. 1984c). Small beakers containing $700 \mu \mathrm{Ci}$ each of $\mathrm{NaH}^{14} \mathrm{CO}_{3}$ were placed in the bags, the bags were sealed, and $1 \mathrm{~N} \mathrm{H}_{2} \mathrm{SO}_{4}$ was injected through the bag into the beakers to introduce ${ }^{14} \mathrm{CO}_{2}$ into the atmosphere within the bag. During the labeling procedure, the cut stems were immersed in water. The stems were incubated under constant illumination for $48 \mathrm{~h}$, removed from the bags, and incubated under natural 
light for an additional $24 \mathrm{~h}$. After labeling, leaves were detached from the stems, dried at $55^{\circ} \mathrm{C}$, and ground to pass a 40 mesh $(425 \mu \mathrm{m})$ screen.

The specific activity of the labeled leaves was determined by combusting weighed portions in an OX-300 Biological Oxidizer (R. J. Harvey Instrument Co., Hillsdale, N. J.) and radioassaying the trapped ${ }^{14} \mathrm{CO}_{2}$ by liquid scintillation spectrometry (Benner et al. 1984a). To determine whether or not the leaves were uniformly labeled, an extractive-free lignocellulose fraction was separated from other plant components by serially extracting $500 \mathrm{mg}$ of material in boiling ethanol $(95 \%)$, ethanol-benzene $(1: 2[\mathrm{vol} / \mathrm{vol}])$, and water (Benner et al. 1984a). The lignocellulose fraction of labeled leaves contained $44.1 \%$ of the total incorporated radioactivity. Leaves contained $48.4 \%$ lignocellulose by weight indicating that the distribution of radioactivity between the leachable and lignocellulosic components of labeled leaves was similar to the natural distribution by weight of these components. Likewise, mangrove leaf material was leached in sterile distilled water at $12{ }^{\circ} \mathrm{C}$ for $7 \mathrm{~d} ; 45.4 \%$ of the radioacitivity was solubilized during leaching and $37.6 \%$ of the dry weight of the material was lost as water-soluble compounds.

Procedures used to prepare and characterize specifically radiolabeled $\left[{ }^{14} \mathrm{C}\right.$-polysaccharide]lignocellulose and $\left[{ }^{14} \mathrm{C}\right.$-lignin]lignocellulose from Rhizophora mangle leaves and wood have been previously described (Benner et al. 1984a). Briefly, the procedure involves immersing the cut ends of plant material in sterile water containing a radioactive precursor of lignin or polysaccharides and allowing the cutting to incorporate the precursor into newly synthesized plant material. Leaves were specifically labeled in the lignin component using $\left[{ }^{14} \mathrm{C}\right]$ cinnamic acid as precursor. Wood was specifically labeled in the lignin component using $\left[{ }^{14} \mathrm{C}\right]$ phenylalanine as precursor. Leaves and wood were both specifically labeled in the polysaccharides, cellulose and hemicellulose, using $\left[{ }^{14} \mathrm{C}\right] \mathrm{glu}-$ cose as precursor. After labeling, leaves and stems were dried $\left(55^{\circ} \mathrm{C}\right)$, ground to pass a 40 mesh screen $(425 \mu \mathrm{m})$, and an extractive-free lignocellulose preparation was separated from unincorporated radioactivity and non-lignocellulosic plant components as described above. Chemical analyses of these preparations have indicated that they are substantially free of radiolabeled contaminants (Benner et al. 1984a) and that their biodegradation accurately tracks overall biodegradation of the lignin and polysaccharide components of lignocellulose (Hodson et al. 1984).

Sampling sites and experimental procedures. The data presented herein were determined during October 1982, on the first of a series of oceanographic cruises aboard the O.R.V. 'Cape Florida' to a mangrove

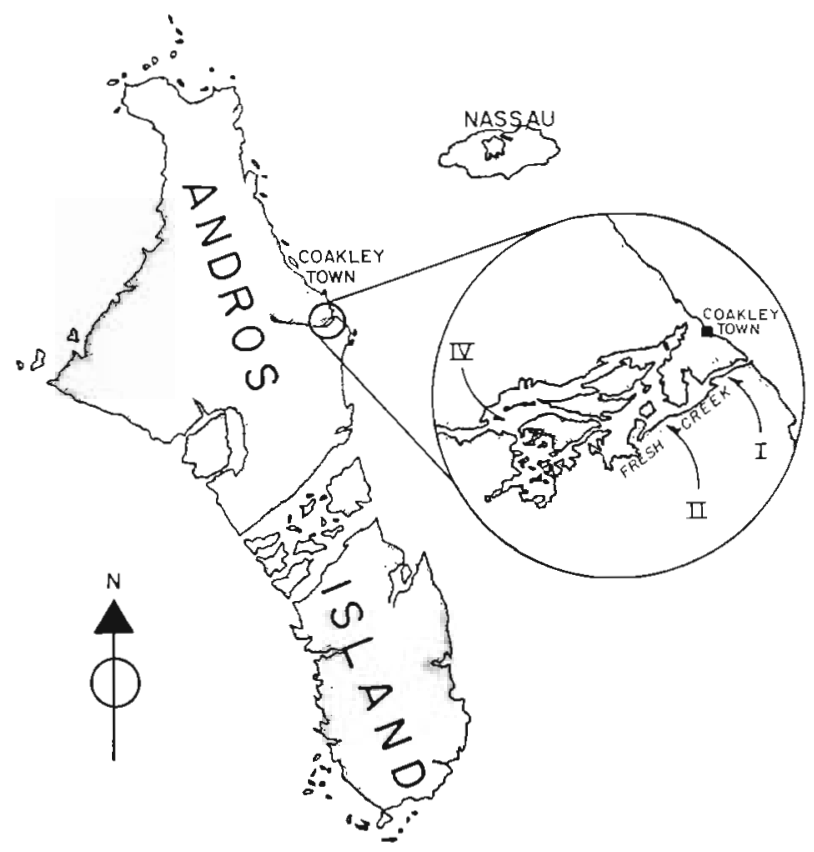

Fig. 1. Location of sampling stations in the Fresh Creek estuary, Andros Island, Bahamas

estuary in the Bahama Islands to study the transformations and fate of mangrove detritus in coastal tropical waters. Andros Island is the largest island in the Bahamas and unlike many of the other islands, Andros has considerable quantities of freshwater. Fresh Creek, a tidal connection between a freshwater lake and oceanic waters, is located on the eastern shore of Andros (Fig. 1) and is navigable by small boat. Rhizophora mangle is the dominant mangrove in the area. Except for patches of luxuriant growth the trees are small (2 to $3 \mathrm{~m}$ ). Station I was located near the mouth of the creek where salinities ranged from 22 to $34 \%$ depending on the tide and rainfall. At Station II salinities ranged from 11 to $15 \%$, and at Station IV salinities ranged from 0 to $4 \%$. Decaying leaf material from surface sediments and water were collected from the above locations, and transported by small boat to the O.R.V. 'Cape Florida'. A slurry consisting of approximately $1.2 \mathrm{~g}$ (dry weight) decaying leaf material and $650 \mathrm{ml}$ of unscreened, unfiltered water was homogenized for $30 \mathrm{~s}$ in a Waring blender and used as an inoculum in aerobic incubations with radiolabeled mangrove leaf or wood material. Of the slurry, $10 \mathrm{ml}$ portions were incubated with $10 \mathrm{mg}$ of radiolabeled substrate in $125 \mathrm{ml}$ bottles equipped with gassing ports (Benner et al. 1984a). Bottles were incubated in the dark with gentle shaking $(100 \mathrm{rpm})$ at the in situ water temperature $\left(30^{\circ} \mathrm{C}\right)$. Subaerial incubations received damp, decaying leaf material and $10 \mathrm{mg}$ of radiolabeled substrate. All bottles were aerated with sterile, $\mathrm{CO}_{2}$-free, humidified air for $15 \mathrm{~min}$ every 48 to 
$72 \mathrm{~h}$ (Benner et al. 1984a). Mineralization of the radiolabeled substrates was monitored at each aeration by trapping the evolved ${ }^{14} \mathrm{CO}_{2}$ in a series of two scintillation vials containing liquid scintillation medium (Benner et al. 1984a). Traps were changed after each aeration, and radioactivity was quantified in a Beckman LS 9000 liquid scintillation spectrometer. The percent total lignocellulose mineralized $\left(\mathrm{LC}_{\mathrm{m}}\right)$ after a given incubation time is calculated as:

$$
\mathrm{LC}_{\mathrm{m}}=\left[\mathrm{L}_{\mathrm{m}}(\mathrm{L})+\mathrm{P}_{\mathrm{m}}(\mathrm{P})\right] / 100
$$

where: $\mathrm{L}_{m}=\%$ lignin mineralized; $\mathrm{P}_{\mathrm{m}}=\%$ polysaccharide mineralized; $\mathrm{L}=\%$ lignin in the lignocellulose; $\mathrm{P}=\%$ polysaccharide in the lignocellulose. Controls were killed with $5 \%$ Formalin (vol/vol, final concentration) and evolved no ${ }^{14} \mathrm{CO}_{2}$ during the incubation period. At the end of the experiment, incubations were analyzed for radiolabeled dissolved organic material. The contents of each bottle were filtered $(0.45 \mu \mathrm{m}$ pore-size Gelman filter), acidified $(\mathrm{pH}<2)$, and the radioactivity in $1 \mathrm{ml}$ subsamples was quantified by liquid scintillation spectrometry (Benner et al. 1984c). All incubations were done in triplicate.

Anoxic sediments were collected from water depths of 0.5 to $1.0 \mathrm{~m}$ at Stations I and IV with $100 \mathrm{~cm}$ by $5.5 \mathrm{~cm}$ sections of plastic (PVC) pipe. Cores were immediately sealed with butyl rubber stoppers and transported to the O.R.V. 'Cape Florida' for processing within $5 \mathrm{~h}$ of collection. Redox potential was measured using an Orion Research Model 901 specific ion meter equipped with a platinum redox electrode. At approximately $5 \mathrm{~cm}$ of depth in cores from Station I and Station $\mathrm{IV}$, the redox potential was $-380 \mathrm{mV}$ and $-316 \mathrm{mV}$, respectively. Sections of the cores at 5 to $10 \mathrm{~cm}$ of depth were placed in a Waring blender specially equipped with gassing ports so that a continuous flow of $\mathrm{N}_{2}$ was maintained in the blender (Benner et al. $1984 \mathrm{~b})$. An equal volume of filter-sterilized $(0.45 \mu \mathrm{m}$ Gelman) deoxygenated water, collected from the station where the core was taken, was added to the blender. After homogenization (1 min) $20 \mathrm{ml} \mathrm{sub-sam-}$ ples were removed from the blender through a sampling port and dispensed into $35 \mathrm{ml}$ serum bottles containing $20 \mathrm{mg}$ of one of the labeled substrates. Serum bottles were stoppered with butyl rubber stoppers (Bellco Glass, Inc., Vineland, N. J.) and aluminum crimp seals were attached. After sealing, the bottles were flushed with $\mathrm{N}_{2}$ for $5 \mathrm{~min}$ and incubated in the dark at $30{ }^{\circ} \mathrm{C}$. Controls were killed with $10 \%$ Formalin (vol/vol, final concentration) and evolved no ${ }^{14} \mathrm{CO}_{2}$ during the incubation period. Total carbon dioxide and methane production were periodically monitored by gas chromatography (Benner at al. 1984b); methane production was quantitatively insignificant relative to carbon dioxide production. Therefore, the production of ${ }^{14} \mathrm{CH}_{4}$ was not quantified. The production of ${ }^{14} \mathrm{CO}_{2}$ was monitored periodically by flushing the incubations with $\mathrm{N}_{2}$ and trapping the evolved ${ }^{14} \mathrm{CO}_{2}$ as described above.

Unlike aerobic incubations which did not accumulate significant percentages of $\left[{ }^{14} \mathrm{C}\right]$ as bicarbonate and carbonate, anaerobic incubations accumulated significant percentages of radiolabel as bicarbonate and carbonate which were quantified at the end of the incubation period. Upon termination of the anaerobic incubations, the contents of each serum bottle were analysed for the presence of dissolved radiolabel (Benner et al. 1984b). Sediment slurries were washed from the serum bottles into $50 \mathrm{ml}$ centrifuge tubes with $20 \mathrm{ml}$ of $2 \%$ saline $(\mathrm{pH} 9)$. The tubes were vortexed and centrifuged $(2100 \mathrm{~g})$ for $10 \mathrm{~min}$. The supernatent was decanted and filtered $(0.45 \mu \mathrm{m}$ pore-size Gelman filter). Total dissolved radiolabel, including inorganic and organic forms, was determined by adding $1 \mathrm{ml}$ of each filtrate to a liquid scintillation medium and quantifying the radioactivity by liquid scintillation spectrometry (Benner et al. 1984b). Dissolved radiolabeled organic material (acid-stable) was determined by acidifying $(\mathrm{pH}<2) 1 \mathrm{ml}$ of each filtrate and assaying for radioactivity as described above.

\section{RESULTS}

The concentrations of lignocellulose and lignin in leaves and wood of living red mangrove Rhizophora mangle are presented in Table 1. Approximately half $(48.4 \%)$ of the dry weight of leaves was determined to be structural, lignocellulosic fiber. The lignocellulose content ( $\%$ dry weight) of mangrove wood was considerably higher $(82.6 \%)$. Leaves and wood were determined to have approximately equal percentages of lignin (16\%). Surprisingly, the lignocellulose in leaves was found to be more highly lignified (i.e. a higher lignin:polysaccharide ratio) than that in the woody plant parts; lignocellulose in the leaves was $66 \%$ polysaccharide and $34 \%$ lignin, whereas, that in the wood was $80 \%$ polysaccharide and $20 \%$ lignin.

Results of previous studies of the decomposition of mangrove leaves enclosed in litter bags and incubated in mangrove estuaries revealed a relatively rapid initial loss of approximately 30 to $50 \%$ of the dry weight of leaves due to leaching of water-soluble components (Heald 1971, Fell et al. 1980, Woodroffe 1982). However, the biological fate of the organic components released during leaching was not followed. To investigate the biodegradability of the leachable components, we prepared uniformly $\left.\right|^{14} \mathrm{C}$ llabeled mangrove leaf material and incubated it aerobically with water and decaying mangrove leaf material collected from 
Table 1. Rhizophora mangle. Lignocellulose and lignin content of leaves and wood

\begin{tabular}{|lccc|}
\cline { 2 - 4 } $\begin{array}{c}\text { Plant } \\
\text { material }\end{array}$ & $\begin{array}{c}\text { Ligno- } \\
\text { cellulose }\end{array}$ & Lignin & $\begin{array}{c}\text { \% lignin of } \\
\text { lignocellulose }\end{array}$ \\
\hline $\begin{array}{l}\text { Leaves } \\
\text { Wood }\end{array}$ & $48.4 \pm 0.2$ & $16.6 \pm 1.4$ & 34.3 \\
- Percentages given on an ash-free dry & weight basis. \\
Mean values of 3 replicates \pm 1 SD & \\
\hline
\end{tabular}

the Fresh Creek estuary at Stations I, II, and IV, at which water salinities were 24,15 , and $4 \%$, respectively, at the time of sampling. Assuming approximately $50 \%$ of the leaf material was leachable, the addition of $10 \mathrm{mg}$ of leaf material would amount to a final concentration of $0.5 \mathrm{~g}^{-1}$ of leachate in each incubation. Considering the relatively high concentration of rapidly leachable tannins present in mangrove leaves (Cundell et al. 1979), we believed this addition could have inhibitory effects on the associated microflora (Basaraba \& Starkey 1966). Nonetheless, initial rates of mineralization were relatively rapid and averaged $5 \% \mathrm{~d}^{-1}$ over the first $6 \mathrm{~d}$ of incubation, presumably due mainly to mineralization of leachable, easily degraded components with some contribution from lignocellulose degradation (Fig. 2). By the end of the $26 \mathrm{~d}$ incubation, rates of mineralization had decreased 10 fold to $0.5 \% \mathrm{~d}^{-1}$. Upon termination of the incubations, 2 to $3 \%$ of the radiolabel in live samples was recovered as dissolved organic (acid-stable) material; whereas, in Formalin killed controls, $64 \%$ of the radiolabel had leached from the leaves by the end of the incubation and was recovered as dissolved organic material. Overall, rates of microbial mineralization of leaf material by samples from the 3 stations, representing a range of in situ salinity values, were approximately equal; after $26 \mathrm{~d}, 44$ to $47 \%$ of the radioactivity was recovered as ${ }^{14} \mathrm{CO}_{2}$. There was no significant difference (Student's T-test) between rates of mineralization of uniformly labeled leaf material in submerged and subaerial incubations from Station II (data not shown).

We determined separately the rates of aerobic biodegradation of the lignin and polysaccharide components of mangrove leaf lignocellulose by the microbial assemblage at Stations I, II, and IV. After $26 \mathrm{~d}, 6.0$ to $14.0 \%$ of the polysaccharide and 2.7 to $4.9 \%$ of the lignin component of the lignocellulose was mineralized (Fig. 3). The polysaccharide component was mineralized 2 times faster than the lignin component in samples from Stations I and IV, and 4 times faster than the lignin component in samples from Station II. The total percentage of lignocellulose mineralized during the $26 \mathrm{~d}$ incubation in samples

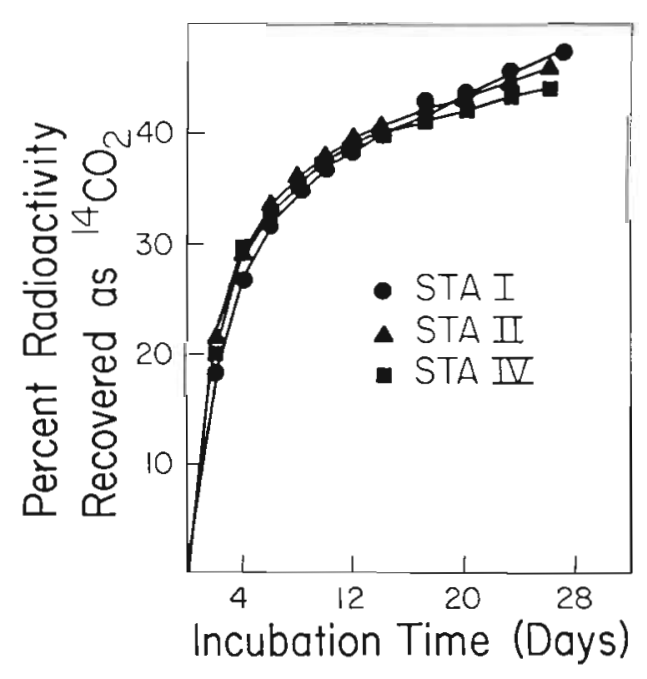

Fig. 2. Mineralization of uniformly $\left[{ }^{14} \mathrm{C}\right]$ labeled, mangrove leaf material in aerobic water-detritus samples at $30^{\circ} \mathrm{C}$ from 3 stations of varying salinity along Fresh Creek (Station I, $24 \%$; Station II, $15 \%$; Station IV, $4 \%$ )

from Stations I and II was calculated to be 8.3 and $10.3 \%$, respectively, whereas only about half as great a percentage $(4.8 \%)$ was mineralized in samples from the low salinity Station IV. The kinetics of mineralization of the lignin and polysaccharide components of mangrove leaves also varied among the 3 stations; mineralization rates at Station I were relatively constant whereas rates of mineralization of the polysaccharide and lignin components of lignocellulose in samples from Stations II and IV decreased up to 2 fold by the end of the incubations. As with uniformly labeled mangrove leaf material, no significant differences (Student's T-test) in rates of lignocellulose mineralization were observed between submerged and subaerial incubations from Station II (data not shown).

Chemical characterization of uniformly $\left[{ }^{14} \mathrm{C}\right]$ labeled leaf material indicated that $56 \%$ of the label was associated with non-lignocellulosic, extractable material. At least this portion of the label in the leaf material was leachable since killed controls contained $64 \%$ of the label as dissolved organic material at the end of the $26 \mathrm{~d}$ incubation. In live incubations from the various stations, 44 to $47 \%$ of the label was recovered as ${ }^{14} \mathrm{CO}_{2}$. The percentage of lignocellulose mineralized over the same incubation period ranged from 5 to $10 \%$ of the lignocellulose depending on the source of sediment microflora. By subtracting the percentage of lignocellulose mineralized from the total percentage of carbon mineralized in incubations containing uniformly labeled material, the percentage of the leachable components that was mineralized during the incubation can be calculated. For instance, in samples from Station I a total of $47 \%$ of the radioactivity from 


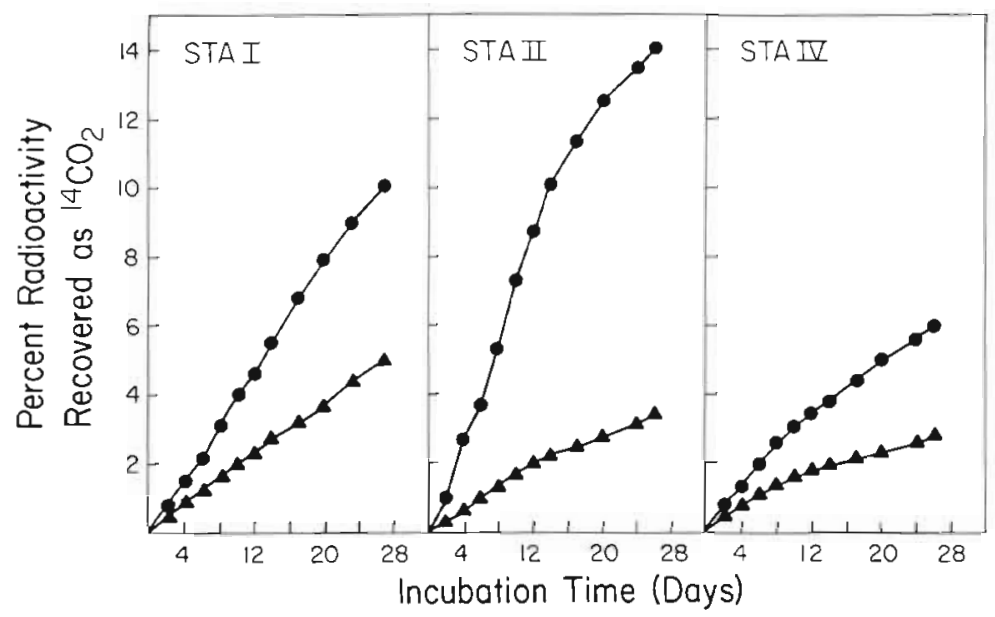

Fig. 3. Aerobic mineralization $\left(30^{\circ} \mathrm{C}\right)$ of $\left[{ }^{14} \mathrm{C}\right.$ lignin]lignocellulose $(\mathbf{\Delta})$ and $\left[{ }^{14} \mathrm{C}\right.$-polysaccharide]lignocellulose (•) from Rhizophora mangle leaves uniformly labeled material was recovered as ${ }^{14} \mathrm{CO}_{2}$ and $8 \%$ of the lignocellulose was mineralized. Therefore, $39 \%$ of the recovered ${ }^{14} \mathrm{CO}_{2}$ in samples with uniformly labeled material originated from leachable components. Since at least $56 \%$ of the radiolabel was in leachable components and very little ( $2 \%$ ) of the label was recovered in soluble from, the percentage of leachable radioactivity incorporated into microbial biomass can be calculated as approximately $17 \%$. Thus, microflora from Station I were approximately $30 \%$ efficient in the conversion of mangrove leachate into microbial biomass. Similiar calculations yielded the same conversion efficiency by microflora from Station IV and a slightly higher conversion efficiency $(36 \%)$ by microflora from Station. II.

Rates of mineralization of the lignin and polysaccharide components of mangrove lignocellulose were determined in samples from Station I. After $26 \mathrm{~d}, 5.8 \%$ of the polysaccharide and $2.8 \%$ of the lignin component of the lignocellulose were mineralized (Fig. 4). As with mangrove leaves, the polysaccharide component of lignocellulose from wood was mineralized at a 2 fold higher rate than the lignin component was mineralized. The total percentage of wood lignocellulose mineralized during the $26 \mathrm{~d}$ incubation was calculated to be $5.2 \%$. Overall, the lignocellulose from mangrove leaves was mineralized 1.6 times faster than lignocellulose from mangrove wood.

The rates of degradation of lignocellulose from mangrove leaves and wood observed in this study were 3 to 5 times slower than rates of degradation of lignocellulose derived from the salt marsh plants Spartina alterniflora and Juncus roemerianus in salt marsh sediments (Benner et al. 1984a). The observed differences in rates of lignocellulose degradation could be due to differences in the biodegrability of the lignocelluloses

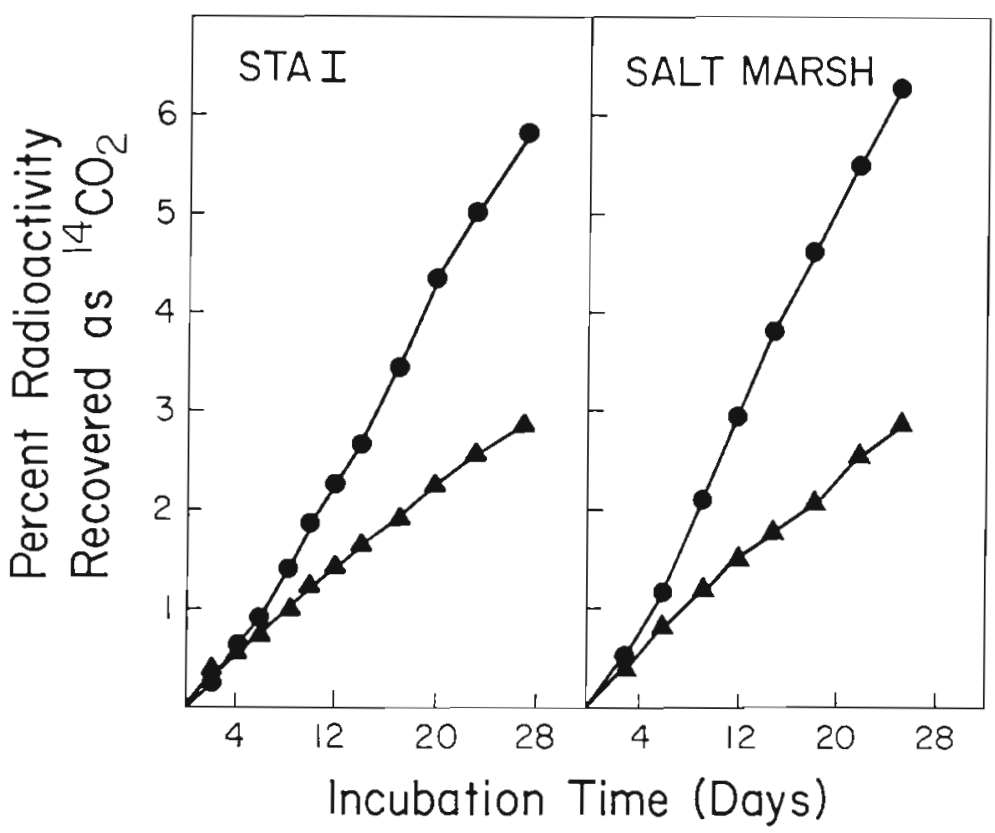

Fig. 4. Aerobic mineralization $\left(30{ }^{\circ} \mathrm{C}\right)$ of $\left[{ }^{14} \mathrm{C}\right.$ lignin]lignocellulose (4) and $\left[{ }^{14} \mathrm{C}\right.$-polysaccharidellignocellulose (•) from Rhizophora mangle wood in water-detritus samples from Station I, Fresh Creek estuary, and water-sediment samples from a temperate salt marsh on Sapelo Island, Georgia 
themselves, or to differences in the biomass and activity of the lignocellulolytic microflora in the 2 estuarine ecosystems. To distinguish between these possibilities we directly compared the rate of mineralization of mangrove wood lignocellulose by the microflora from Fresh Creek estuary with the rate of mineralization of mangrove lignocellulose by the microflora from a temperate salt marsh on Sapelo Island, Georgia. If either environment, due to chemical or microbiological reasons, were more favorable for lignocellulose degradation, then rates of mineralization by natural microbial assemblages from that system should be higher than rates by natural microbial assemblages from the other environment. On the other hand, if the microbial assemblages from the salt marsh and mangrove swamp had similar lignocellulolytic activities then mangrove wood lignocellulose should be mineralized at similiar rates by microbial assemblages from the 2 ecosystems. Total percentages of lignocellulose mineralized and the kinetics of mineralization of the polysaccharide and lignin components of mangrove wood lignocellulose in salt marsh sediment and water $(20 \%$ S) were essentially identical to total percentages of lignocellulose mineralized and kinetics of mineralization supported in water-detritus samples from Station I $(24 \%$ S) in the mangrove estuary (Fig. 4). These results and the results of our previous studies (Hodson et al. 1983, Benner et al. 1984a) indicate that mangrove lignocellulose is less biodegradable than lignocellulose from the salt marsh plants $S$. alterniflora and $J$. roemerianus. After $26 \mathrm{~d}$ of incubation, approximately $6 \%$ of the polysaccharide component and $3 \%$ of the lignin component were mineralized by the natural microbial assemblage from each environment.

Time courses of the anaerobic mineralization of uniformly labeled leaf material during long-term (246 d) incubations are presented in Fig. 5. By the end of the incubation, 13.1 and $16.8 \%$ of the radioactivity in uniformly labeled leaf material was recovered as ${ }^{14} \mathrm{CO}_{2}$ from incubations with anoxic sediment from Stations I and IV, respectively. The kinetics of mineralization of uniformly labeled material under anaerobic conditions were similar to the kinetics under aerobic conditions, however, mineralization rates were 25 to 30 times lower under anaerobic conditions. Assessment of the percentage of material mineralized to $\mathrm{CO}_{2}$ is only a partial estimate of degradation. Methane production was not quantitatively significant; $_{i}$ however, formation of dissolved organic and inorganic degradation products was significant (Table 2 ). When the additional radiolabel recovered in total soluble form at the end of the incubation is taken into account, the calculated total percentage of degradation increased by approximately $100 \%$. Most (50 to $75 \%$ ) of the dissolved radiolabeled material was acid-volatile

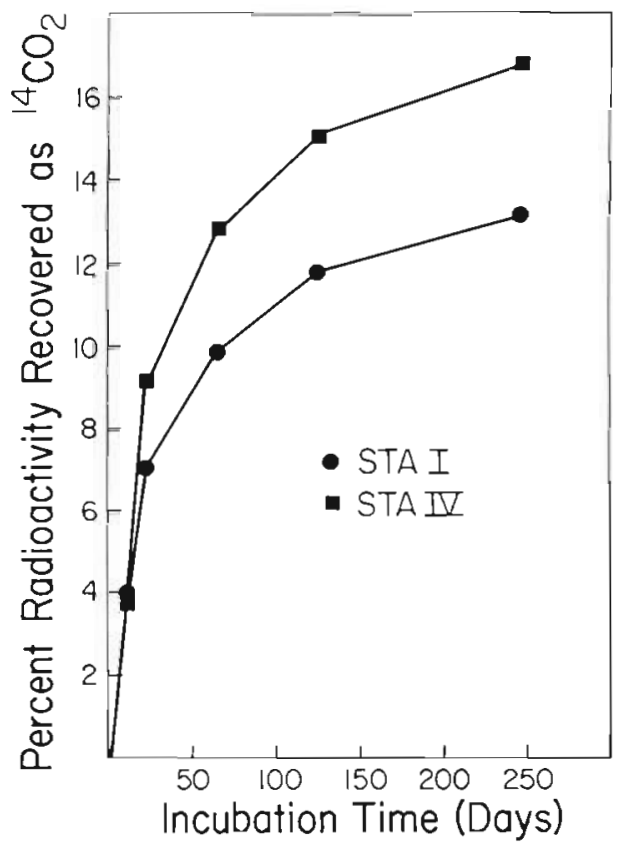

Fig. 5. Anaerobic mineralization $\left(30^{\circ} \mathrm{C}\right)$ of uniformly $\left[{ }^{14} \mathrm{C}\right]$ labeled, mangrove leaf material in anoxic sediments from 2 stations along Fresh Creek

(presumably $\mathrm{HCO}_{3}^{-1}$ and $\mathrm{CO}_{3}{ }^{-2}$ ) indicating that it was microbially mineralized.

We also incubated specifically labeled $\left[{ }^{14} \mathrm{C}\right.$-polysaccharide]lignocelluloses and $\left[{ }^{14} \mathrm{C}\right.$-lignin]lignocelluloses from mangrove leaves and wood under anaerobic conditions with sediment from Stations I and IV. Unlike the aerobic incubations in which leaf lignocellulose was mineralized faster than wood lignocellulose, leaf lignocellulose and wood lignocellulose were mineralized at approximately equal rates under anaerobic conditions. After $246 \mathrm{~d}, 4.7$ and $6.3 \%$ of the polysaccharide component of leaf lignocellulose was recovered as ${ }^{14} \mathrm{CO}_{2}$ from incubations with anoxic sediment from Stations I and IV, respectively (Fig. 6). After the same incubation period a total of 1.4 and $1.1 \%$ of the lignin component of leaf lignocellulose was recovered as ${ }^{14} \mathrm{CO}_{2}$ from incubations with sediment from Stations I and IV, respectively. During the same incubation period, 4.1 and $5.6 \%$ of the polysaccharide component of wood lignocellulose were mineralized in sediment from Stations I and IV, respectively (Fig. 6). A total of 1.5 and $1.0 \%$ of the lignin component of lignocellulose from wood was mineralized in sediment from Stations I and IV, respectively. When the additional dissolved radiolabel recovered at the end of the incubations is taken into account, the calculated total percentages of degradation are higher by 2 to 3 fold. Incubations with sediments from Station IV consistently contained slightly greater percentages of radiolabel recovered as ${ }^{14} \mathrm{CO}_{2}$ and less dissolved 
Table 2. Budget for the fate of mangrove detritus in anaerobic sediments after $246 \mathrm{~d}$. Radiolabel (\%) from uniformly radiolabeled mangrove leaves and specifically radiolabeled lignocellulose from Rhizophora mangle recovered as $\mathrm{CO}_{2}$, dissolved organic (acid-stable) material, total dissolved material $(\mathrm{pH} \mathrm{9),} \mathrm{and} \mathrm{the} \mathrm{total} \mathrm{percentage} \mathrm{of} \mathrm{radiolabel} \mathrm{recovered}$

\begin{tabular}{|c|c|c|c|c|}
\hline \multirow{2}{*}{$\begin{array}{c}{ }^{14} \mathrm{C} \text {-labeled } \\
R . \text { mangle }\end{array}$} & \multicolumn{4}{|c|}{$\%$ radioactivity recovered as } \\
\hline & $\mathrm{CO}_{2}$ & $\begin{array}{c}\text { Dissolved } \\
\text { organic } \\
\text { material }\end{array}$ & $\begin{array}{c}\text { Total } \\
\text { dissolved } \\
\text { material }\end{array}$ & $\begin{array}{c}\text { Total } \\
\text { decomposition }\end{array}$ \\
\hline \multicolumn{5}{|c|}{ Uniformly-labeled leaves } \\
\hline STA I & 13.1 & 4.7 & 15.7 & 28.8 \\
\hline STA IV & 16.8 & 3.4 & 10.8 & 27.6 \\
\hline \multicolumn{5}{|l|}{ (Lignin-LC) leaves } \\
\hline STA I & 1.4 & 2.2 & 4.0 & 5.4 \\
\hline STA IV & 1.1 & 1.3 & 2.8 & 3.9 \\
\hline $\mathrm{KC}$ & 0 & 1.2 & 1.2 & 1.2 \\
\hline \multicolumn{5}{|c|}{ (Polysaccharide-LC) leaves } \\
\hline STA I & 4.7 & 2.5 & 7.5 & 12.2 \\
\hline STA IV & 6.3 & 3.2 & 6.5 & 12.8 \\
\hline $\mathrm{KC}$ & 0 & 2.7 & 2.7 & 2.7 \\
\hline \multicolumn{5}{|l|}{ (Lignin-LC) wood } \\
\hline STA I & 1.5 & 1.0 & 2.6 & 4.1 \\
\hline STA IV & 1.0 & 0.6 & 1.5 & 2.5 \\
\hline \multicolumn{5}{|c|}{ (Polysaccharide-LC) wood } \\
\hline STA I & 4.1 & 2.9 & 8.8 & 12.9 \\
\hline STA IV & 5.6 & 1.6 & 4.5 & 10.1 \\
\hline
\end{tabular}

radiolabel than did incubations with sediments from Station I. Overall, under anaerobic conditions rates of mineralization of the polysaccharide components of mangrove lignocelluloses were 3 to 5 times faster than rates of degradation of the lignin components.

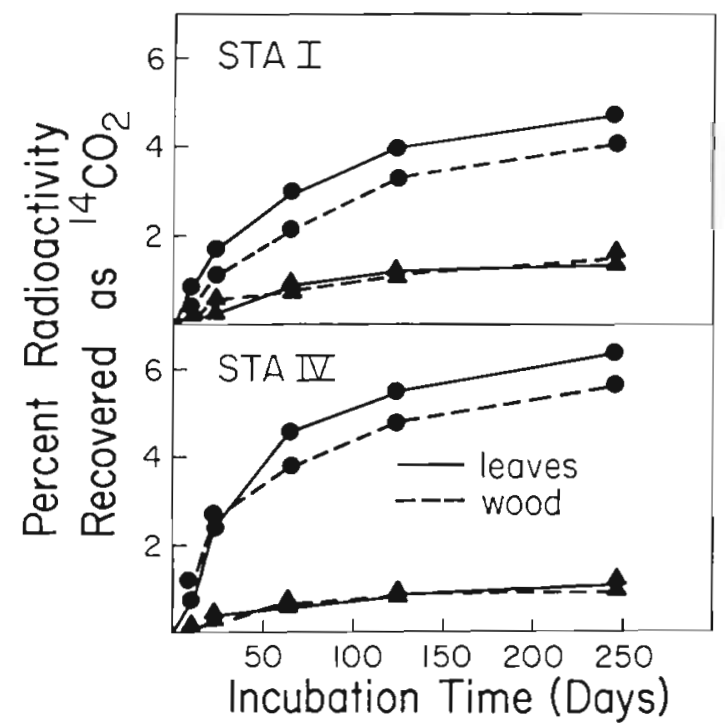

Fig. 6. Anaerobic mineralization $\left(30^{\circ} \mathrm{C}\right)$ of $\left[{ }^{14} \mathrm{C}\right.$-lignin]lig-

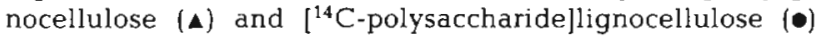
from mangrove leaves and wood in anoxic sediments from 2 stations along Fresh Creek

\section{DISCUSSION}

Initial rates of microbial mineralization of mangrove leaf material presented here are similar to initial rates of weight loss determined in field studies using litter bags (Heald 1971, Fell et al. 1980, Woodroffe 1982), indicating that the bulk of the organic matter that leaches from mangrove leaves is rapidly utilized by aquatic microflora. Considering the efficiency (30 to $36 \%$ ) of microbial conversion of the leachable portion of mangrove leaves, it appears that a significant percentage of mangrove detritus is relatively rapidly assimilated into microbial biomass and thus potentially available to higher trophic levels in the aquatic food web.

After leaching of water-soluble material, rates of weight loss of the remaining fibrous portion of mangrove leaves in litter bags, presumably lignocellulose, are 5 to 10 times lower than the initial rates of weight loss (Heald 1971, Fell et al. 1980, Woodroffe 1982). Similiarly, we found that mangrove lignocellulose was microbially mineralized at rates approximately 10 fold lower than rates of microbial mineralization of the leachable components of mangrove leaves. We did not determine the efficiency of microbial assimilation of carbon derived from lignocellulose, but Newell et al. (1983) estimated that water-column bacteria convert 
aged salt-marsh detritus, which is approximately 80 to $90 \%$ lignocellulose (Hodson et al. 1984), into bacterial biomass with 9 to $14 \%$ efficiency. Bacterial conversion efficiencies of salt-marsh detritus as high as $38 \%$ were obtained when ammonia was added to the seawater incubations, suggesting that conversion efficiencies may be higher in sediments where ammonia regeneration occurs (Newell et al. 1983). Thus, microbial production at the expense of mangrove detritus may support significant secondary production in the estuarine waters and sediments of mangrove swamps as speculated by Odum \& Heald (1972).

Unlike the unextracted leaf material, lignocellulose from mangrove leaves was mineralized at different rates at the 3 stations along Fresh Creek. Rates of biodegradation of mangrove lignocellulose were higher in samples from Stations with salinities ranging from 24 to $15 \%$ (I and II) relative to the low salinity (4\%) Station IV. Differences in mineralization rates could reflect differences in environmental factors at the stations, such as variations in the size and diversity of the lignocellulolytic microbial populations, inorganic and organic nutrient concentrations, or protozoan and ciliate grazing pressure, which have been shown to effect rates of detritus degradation in other aquatic environments (Fenchel 1977, Fenchel \& Jørgensen 1977, Brinson et al. 1981, Aumen et al 1983). Heald (1971) observed higher rates of weight loss from mangrove leaves contained in litter bags suspended in seawater than from litter bags suspended in low salinity water and attributed the difference to the greater abundance and activity of amphipods in seawater.

Surprisingly, the mangrove swamp and the saltmarsh sediment microflora examined in this study exhibited almost identical lignocellulolytic activities. Lignocelluloses derived from mangrove leaves and wood were more resistant to microbial degradation than lignocelluloses derived from other marine macrophytes that we have examined. Benner et al. (in press) found a high linear correlation between the lignin-to-nitrogen ratio of lignocellulose preparations and their biodegradability; lignocellulose preparations with a relatively high lignin-to-nitrogen ratio, such as Rhizophora mangle lignocellulose, were more resistant to biodegradation than lignocellulose preparations with a low lignin-to-nitrogen ratio, such as Spartina alterniflora lignocellulose.

We did not detect any differences in mineralization rates of specifically radiolabeled lignocelluloses whether they were incubated in submerged or subaerial conditions. Similiarly, uniformly labeled leaf material was mineralized at the same rate whether incubated in submerged or subaerial conditions. Abundant fungal growth was observed in most of the subaerial incubations, suggesting that fungi may have mediated degradation of the leaf material. Fungi have frequently been observed on decaying mangrove leaves and data has been presented implicating fungi in the early stages of decomposition of mangrove leaves (Kohlmeyer \& Kohlmeyer 1979, Fell \& Master 1980, Fell et al. 1980, Fell \& Newell 1981). However, our recent investigations of the relative contributions of fungi and bacteria to the degradation of lignocellulose in submerged incubations indicate that bacteria are the predominant degraders of mangrove lignocellulose in waters and sediments from the Fresh Creek estuary, suggesting that fungi may not significantly contribute to the latter stages of degradation of mangrove detritus (R. Benner, M. A. Moran, and R. E. Hodson unpubl.).

Sediments in mangrove communities are frequently highly organic and anoxic within a few centimeters of the sediment-water interface (Linden \& Jernelöv 1980). Therefore, anaerobic degradation of mangrove detritus is likely to be an important pathway of carbon flow in mangrove ecosystems. Until recently, lignin was believed to be totally inert to anaerobic biodegradation (Hackett et al. 1977, Zeikus et al. 1982). However, Benner et al. (1984b) reported low, but significant, rates of anaerobic biodegradation of synthetic $\left[{ }^{14} \mathrm{C}\right] \mathrm{lig}-$ nin and $\left[{ }^{14} \mathrm{C}\right.$-lignin|lignocelluloses from several aquatic plants in anoxic marine and freshwater sediments. In the present study, rates of anaerobic biodegradation of the lignin and polysaccharide components of mangrove leaves and wood were extremely low. The ratio of polysaccharide-to-lignin mineralized under anaerobic conditions was similiar to but slightly higher than the ratio of polysaccharide-to-lignin mineralized under aerobic conditions, suggesting that biodegradation of the polysaccharide component of mangrove lignocelluloses is tightly coupled with biodegradation of the lignin component. Low rates of anaerobic biodegradation of mangrove lignocellulose indicate a long residence time for mangrove detritus in anoxic sediments and suggest that a relatively small portion of the carbon and energy is available to the food web under these conditions.

Acknowledgements. We thank Dr. A. E. Maccubbin for assistance with several experiments. This work was supported by National Science Foundation grant OCE-81117834 and grant NA 80AA-D-00091 from the National Sea Grant Program, US Department of Commerce.

\section{LITERATURE CITED}

Aumen, N. G., Bottomley, P. J., Ward, G. M., Gregory, S. V. (1983). Microbial decomposition of wood in streams: distribution of microflora and factors affecting $\left[{ }^{14} \mathrm{C}\right]$ lignocellulose mineralization. Appl. environ. Microbiol. 46: 1409-1416

Basaraba, J., Starkey, R. L. (1966). Effect of plant tannins on decomposition of organic substances. Soil Sci. 101: 17-23 
Benner, R., Maccubbin, A. E., Hodson, R. E. (1984a). Preparation, characterization, and microbial degradation of specifically radiolabeled ${ }^{14} \mathrm{C}$-lignocelluloses from marine and freshwater macrophytes. Appl. environ. Microbiol. 47: 381-389

Benner, R., Maccubbin, A. E., Hodson, R. E. (1984b). Anaerobic biodegradation of the lignin and polysaccharide components of lignocellulose and synthetic lignin by sediment microflora. Appl. environ. Microbiol. 47: 998-1004

Bennet, R., Newell, S. Y., Maccubbin, A. E., Hodson, R. E. (1984c). Relative contributions of bacteria and fungi to rates of degradation of lignocellulosic detritus in saltmarsh sediments. Appl. environ. Microbiol. 48: 36-40

Benner, R., Moran, M. A., Hodson, R. E. (in press). Effects of $\mathrm{pH}$ and plant source on lignocellulose biodegradation rates in two wetland ecosystems, the Okefenokee Swamp and a Georgia salt marsh. Limnol. Oceanogr.

Brinson, M. M., Lugo, A. E., Brown, S. (1981). Primary productivity, decomposition and consumer activity in freshwater wetlands. Ann. Rev. Ecol. Syst. 12: 123-161

Crawford, R. L. (1981). Lignin biodegradation and transformation. Wiley Interscience, New York

Cundell, A. M., Brown, M. S., Stanford, R., Mitchell, R. (1979). Microbial degradation of Rhizophora mangle leaves immersed in the sea. Estuar. coast. mar. Sci. 9: 281-286

Fell, J. W., Master, I. M. (1980). The association and potential role of fungi in mangrove detrital systems. Botanica mar. 23: $257-263$

Fell, J. W., Master, I. M., Newell, S. Y. (1980). Laboratory model of the potential role of fungi in the decomposition of red mangrove Rhizophora mangle leaf litter. In: Tenore, $\mathrm{K}$ R., Coull, B. C. (ed.) Marine benthic dynamics. Univ. South Carolina Press, Columbia, p. 359-372

Fell, J. W., Newell, S. Y. (1981). Role of fungi in carbon flow and nitrogen immobilization in coastal marine plant litter systems. In: Wicklow, D. T., Carroll, G. C. (ed.) The fungal community. Marcel Dekker Inc, New York, p. 665-678

Fenchel, T. (1977). Aspects of decomposition of seagrasses. In: McRoy, C. P., Hellferich, C. (ed.) Seagrass ecosystems a scientific perspective. Marcel Dekker, New York, p. 123-145

Fenchel, T. M., Jørgensen, B. B. (1977). Detritus food chains of aquatic ecosystems: the role of bacteria. In: Alexander, $\mathrm{A}$. (ed.) Advances in microbial ecology. Plenum Press, New York, p. 1-58
Hackett, W. F., Connors, W. J., Kirk, T. K., Zeikus, J. G. (1977). Microbial decomposition of synthetic ${ }^{14} \mathrm{C}$-labeled lignins in nature: lignin biodegradation in a variety of natural materials. Appl. environ. Microbiol. 33: 43-51

Heald, E. J. (1971). The production of organic detritus in a south Florida estuary. Univ. Miami Sea Grant Tech. Bull. 6: $1-110$

Hodson, R. E., Benner, R., Maccubbin, A. E. (1983). Transformations and fate of lignocellulosic detritus in marine environments. In: Oxley, T. A., Barry, S. (ed.) Biodeterioration 5. John Wiley \& Sons Publishers, New York, p. $185-195$

Hodson, R. E., Christian, R. R., Maccubbin, A. E. (1984). Lignocellulose and lignin in the salt marsh grass, Spartina alterniflora: initial concentrations and short-term postdepositional changes in detrital material. Mar. Biol. 81 . $1-7$

Kohlmeyer, J., Kohlmeyer, E. (1979). Marine mycology. The higher fungi. Academic Press, Inc., New York

Linden, O., Jernelöv, A. (1980). The mangrove swamp - an ecosystem in danger. Ambio 9: 81-88

Lugo, A. E., Snedaker, S. C. (1974). The ecology of mangroves. Ann. Rev. Ecol. System. 5: 39-64

Maccubbin, A. E., Hodson, R. E. (1980). Microbial degradation of detrital lignocelluloses by salt marsh sediment microflora. Appl. environ. Microbiol. 40: 735-740

Mann, K. H. (1972). Macrophyte production and detritus food chains in coastal waters. Memorie Ist. ital. Idrobiol. 29 (Suppl.): $353-383$

Newell, R. C., Linley, E. A. S., Lucas, M. I. (1983). Bacterial production and carbon conversion based on saltmarsh plant debris. Estuar. coast. Shelf. Sci. 17: 405-419

Odum, W. E., Heald, E. J. (1972). Trophic analyses of an estuarine mangrove community. Bull, mar. Sci. 22: $671-738$

Rodelli, M. R., Gearing, J. N., Gearing, P. J., Marshall, N., Sasekumar, A. (1984). Stable isotope ratio as a tracer of mangrove carbon in Malaysian ecosystems. Oecologia (Berl.) 61: 326-333

Woodroffe, C. D. (1982). Litter production and decomposition in the New Zealand mangrove, Avicennia Marina var. resinifera. N. Z. Jl mar. Freshwat. Res. 16: 179-188

Zeikus, J. G., Wellstein, A. L., Kirk, T. K. (1982). Molecular basis for the biodegradative recalcitrance of lignin in anaerobic environments. FEMS Microbiol. Lett. 15: $193-197$

This paper was presented by Professor S. P. Meyers; it was accepted for printing on March 15, 1985 